\title{
MÁGNESES SÍKFELÜLETHENGERLŐ SZERSZÁMMAL LÉTREHOZOTT ÉL-LEKEREKITÉS TECHNOLÓGIAI PARAMÉTEREINEK OPTIMALIZÁLÁSA
}

\section{OPTIMIZATION OF TECHNOLOGICAL PARAMETERS OF EDGE-ROUNDING AFTER MAGNETIC ASSISTED BALL BURNISHING}

\author{
Kovács Zsolt Ferenc ${ }^{1,4}$, Kodácsy János ${ }^{1}$, Viharos Zsolt János ${ }^{2,3}$ \\ ${ }^{1}$ Neumann János Egyetem, GAMF Kar, Jármütechnológia Tanszék, Magyarország, H-6000 Kecskemét, \\ Izsáki út 10. kovacs.zsolt@gamf.uni-neumann.hu, kodacsy.janos@gamf.uni-neumann.hu \\ ${ }^{2}$ Neumann János Egyetem, Gazdaságtudományi Kar, Közgazdaságtan és Jog Tanszék, Magyarország, \\ H-6000 Kecskemét, Izsáki út 5. \\ ${ }^{3}$ Számítástechnikai és Automatizálási Kutatóintézet, Magyarország, H-1111 Budapest, Kende u. 13-17. \\ viharos.zsolt@sztaki.hu \\ ${ }^{4}$ Budapesti Műszaki és Gazdaságtudományi Egyetem, Gyártástudomány és -technológia Tanszék, \\ Magyarország, 1111. Budapest, Müegyetem rkp.3. kovacszs@manuf.bme.hu \\ https://doi.org/10.47833/2020.2.ENG.001
}

\section{Kulcsszavak: \\ felülethengerlés \\ mágnesesség \\ sorja \\ él-lekerekítés}

\section{Keywords:}

ball burnishing

magnetism

burr

edge-rounding

\section{Cikktörténet:}

Beérkezett 2020. június 09.

Átdolgozva 2020. június 12.

Elfogadva 2020. június 15.

\begin{abstract}
Összefoglalás
A szerzők a sorja eltávolitását és az élek lekerekitését vizsgálják a mágneses síkfelülethengerlő szerszám használatával. Kísérleteik során Taguchi féle kísérlettervezési módszert alkalmazva vizsgálják az egyes technológiai paraméterek (hengerlési sebesség, előtoló sebesség, forgásirány és szerszámtúllógás) él-lekerekitésre gyakorolt hatását. $A$ kísérletek során eredményesen alakítottak ki különböző méretü lekerekitett éleket, továbbá optimális technológiai paramétereket is meghatároztak. A kiértékeléshez modern informatikai eszközöket és berendezéseket használtak.
\end{abstract}

\begin{abstract}
The authors investigate burr removing and edge-rounding using a magnetic assisted ball burnishing tool. In their experiments, the effect of each technological parameter (rolling speed, feed, direction of rotation and tool overhang) on edge rounding is investigated using Taguchi's experimental design method. During the experiments, rounded edges of different sizes were successfully formed, and optimal technological parameters were also determined. For the evaluation modern IT tools and equipment were used.
\end{abstract}

\section{Bevezetés}

A fém alkatrészek forgácsoló megmunkálásakor minden esetben keletkezik a végtermék felhasználhatóságát jelentős mértékben befolyásoló sorja. A sorja a megmunkálás után a munkadarabon maradt anyagfelesleget jelenti, amely az esetek nagy részében a szerszámnak a munkadarabba való be-, vagy munkadarabból történő kilépésekor jön létre. Nagyon sokféle alakban, 
méretben jelentkezik megmunkálást követően, keletkezését számtalan körülmény befolyásolja [1-3], így a sorja típusa is többféle lehet [4].

A sorja eltávolítását és ezzel egy időben az él lekerekítését több szempont is indokolja, többek közt balesetveszélyes, az alkatrészek összeszerelését is gátolhatja, surlódó felületeknél karcolásokhoz vezethet, illetve esztétikai szempontból sem előnyös. Eltávolítására és az éllekrekítés kialakítására számos, az iparban is alkalmazott eljárás létezik [5-7], azonban ezek forgácsolással alakítják ki a sorjamentes, lekerekített élt. Mindez maga után vonja, hogy minimális sorja mindig hátra marad a forgácsolásból eredendően.

A mágneses síkfelület hengerlő szerszám képlékenyen alakítja vagy eltávolítja a sorját, így létrehozva egy ténylegesen sorjamentes él-lekerekítést. A sorja eltávolítása ennél az eljárásnál oly módon valósulhat meg, hogy az letörik, de az esetek döntő többségében csupán elönyösen deformálódik.

\subsection{Az állandó mágneses síkfelülethengerlő szerszám}

A mágneses síkfelülethengerléskor a szerszám adott fordulatszámmal egyenes vonalú vagy adott pálya szerinti mozgást végezve végighalad a munkadarab felületén. A szerszám különlegessége, hogy a hengerlőerő a mágnes erő felhasználásával hozható létre a szerszám végén lévő célszerüen kialakított kúpon. A szerszám részletes bemutatása és alkalmazási lehetőségei a szerzők korábbi cikkeikben megtalálhatók [8-10].

A mágneses síkfelület hengerlő szerszámmal a sorjátlanítás/él-lekerekítés olyan módon valósulhat meg, hogy a síkfelület hengerlése folyamán a szerszám a munkadarab széléhez érve nem áll meg, hanem bizonyos mértékig „túlfut” azon, ezáltal az élen/sorján legördül, ilyen módon megvalósítva a kívánt sorjátlanítást és él-lekerekítést (1. ábra).

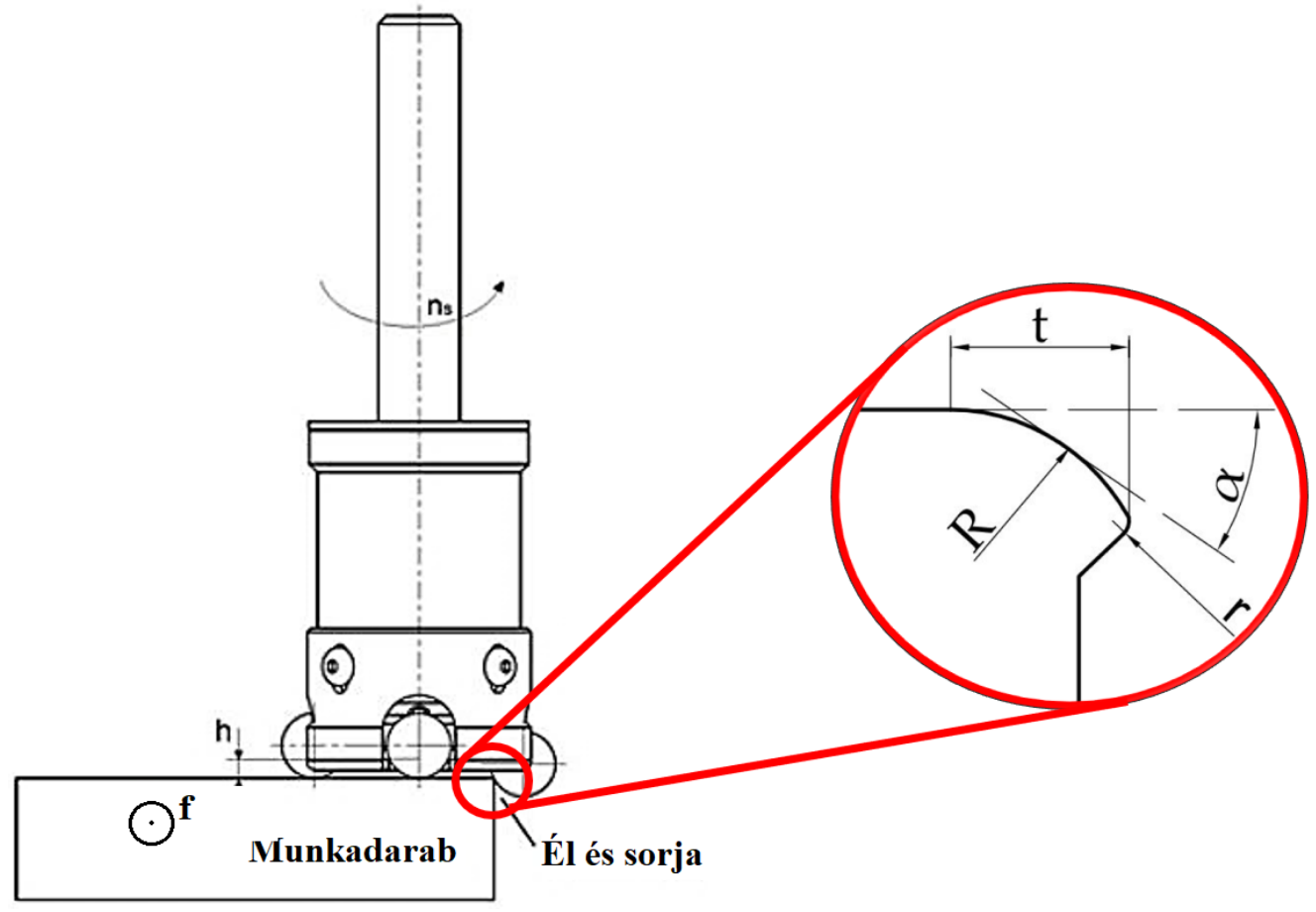

1. ábra. Él-lekerekités folyamata és a hengerléssel létrehozott él-lekerekités paraméterei

A gyakorlatilag sorjamentes (mikrosorjás) munkadarab esetében is az 1. ábrán látható módon jön létre az él-lekerekítés. A kutatás során a szerzők a lekerekített élt jellemző $R, t$ és $\alpha$ méretek változását vizsgálták. Az $r$ méretnek a felhasználás és egyéb szempontból sincs szerepe, ezért annak vizsgáltára nem terjedt ki a kutatás.

\section{A kísérleti munka ismertetése}

A kísérletekhez síkban mart munkadarabokat használtunk, melyeket Taguchi féle kísérlettervezési módszer alkalmazásával elöre megtervezett technológiai paraméterekkel 
hengereltünk, hogy lekerekítsük az élt. A technológiai paraméterek kiválasztásakor elsődlegesen az él-lekerekítésre hatással lévőket részesítettük előnyben.

\subsection{Felhasznált munkadarab anyag}

Az előgyártmány melegen hengerelt C45 acél, $300 \mathrm{~mm}$ hosszú, $75 \mathrm{~mm}$ széles és $20 \mathrm{~mm}$ vastagságú. A munkadarab síkmarását, illetve az él-lekerekítő kísérleteket egy Kondia B-640 tipusú háromtengelyes megmunkáló központon hajtottuk végre. A síkmaráshoz homlokmarót használtunk, az alkalmazott technológiai paramétereket az 1. táblázat tartalmazza.

1. táblázat. A marásnál alkalmazott technológiai paraméterek

\begin{tabular}{lc}
\hline Fogásvételek száma, $i(\mathrm{db})$ & 2 \\
Fogásmélység, $a_{p}(\mathrm{~mm})$ & 1,5 \\
Forgácsolósebesség, $v_{\mathrm{c}}(\mathrm{m} / \mathrm{min})$ & 200 \\
Előtolás, $v_{\mathrm{f}}(\mathrm{mm} / \mathrm{min})$ & 150 \\
Szerszám csúcssugár lekerekítés, $r_{\varepsilon}(\mathrm{mm})$ & 0,8 \\
\hline
\end{tabular}

\subsection{Kísérlettevezés}

A szerzők a kísérlettervezéshez Taguchi féle módszert használtak, mivel a kísérletek több faktort tartalmaztak és ezzel a módszerrel a szükséges kísérletek száma viszonylag alacsony szinten tartható. A kísérlettervnek 4 faktora és 4 szintje van, kivétel a megmunkálási irány ( $D$ faktor), mert csak két irány (egyenirány és ellenirány) lehetséges, így itt ez a 2 faktor került a kísérlettevbe. $A z$ előtoló sebesség ( $A$ faktor) és a hengerlési sebesség ( $B$ faktor) értékeit a szerzők korábbi cikkeikben már vizsgálták, így azon tapasztalatokat felhasználva határozták meg a mostani értékeket [9-11]. A szerszám túlfutásának (C faktor) értéke a szerszámban megtalálható 4 darab $\varnothing 16 \mathrm{~mm}$-es golyó átmérőnél kisebbre lett véve, nehogy megakadjon. A kiválasztott szintek értékeit a 2. táblázat tartalmaz.

2. táblázat. Az alkalmazott technológiai paraméterek értékei

\begin{tabular}{|c|c|}
\hline Faktorok & Szintek \\
\hline A $\quad$ Előtoló sebesség, $v_{f}(\mathrm{~mm} / \mathrm{min})$ & $20 ; 40 ; 60 ; 80$ \\
\hline Hengerlési sebesség, $v_{h}(\mathrm{~m} / \mathrm{min})$ & $30 ; 50 ; 70 ; 90$ \\
\hline Szerszám túlfutás, b (mm) & $6 ; 8 ; 10 ; 12$ \\
\hline D Megmunkálás iránya (1-egyen / 2-ellen) & $1 ; 2$ \\
\hline
\end{tabular}

A kísérlet menetét tartalmazó választáblázat a Minitab 17 statisztikai szoftverben készült. $\mathrm{A}$ rendelkezésre álló technológiai paraméterek alapján az L16 $\left(4^{\wedge} 3\right)\left(2^{\wedge} 1\right)$ típusú kísérlettervet választottuk az optimális technológiai paraméterek és az egyes faktorok hatásainak a meghatározásához (3. táblázat).

\section{3. táblázat. Taguchi-módszer szerinti kísérletterv}

\begin{tabular}{|c|c|c|c|c|}
\hline \multirow{2}{*}{ Szintek } & \multicolumn{4}{|c|}{ Faktorok } \\
\hline & $\mathbf{A}$ & B & C & D \\
\hline 1 & 20 & 30 & 6 & 1 \\
\hline 2 & 20 & 50 & 8 & 2 \\
\hline 3 & 20 & 70 & 10 & 1 \\
\hline 4 & 20 & 90 & 12 & 2 \\
\hline 5 & 40 & 30 & 8 & 1 \\
\hline 6 & 40 & 50 & 6 & 2 \\
\hline 7 & 40 & 70 & 12 & 1 \\
\hline 8 & 40 & 90 & 10 & 2 \\
\hline 9 & 60 & 30 & 10 & 2 \\
\hline 10 & 60 & 50 & 12 & 1 \\
\hline 11 & 60 & 70 & 6 & 2 \\
\hline 12 & 60 & 90 & 8 & 1 \\
\hline 13 & 80 & 30 & 12 & 2 \\
\hline 14 & 80 & 50 & 10 & 1 \\
\hline 15 & 80 & 70 & 8 & 2 \\
\hline 16 & 80 & 90 & 6 & 1 \\
\hline
\end{tabular}


A kísérlet, jellegéböl adódóan, nem indokol több végrehajtást. A mágneses síkfelülethengerlésnél, a forgácsoláshoz hasonlóan, olyan zavaró tényezők és hatások keletkeznek melyek állandóan fennálnak, így a folyamat jól reprodukálható.

\section{A kísérlet eredményei}

A kísérlet végrehajtását követően a kialakított él-lekerekítések Mitutoyo Formtracer SV-C3000 felületi érdesség- és kontúrmérővel mérték. A kapott eredmények alapján vizsgáltuk az egyes faktorok hatását, és az optimális technológiai parmétereket is megállapítottuk.

\subsection{Az él-lekerekítés mérése}

Az él-lekerekítés méréséhez a munkadarabot $45^{\circ}$-al be kell dönteni, hogy az elméleti él meröleges szöget zárjon be a kontúrmérő tapintójával, amihez egy $45^{\circ}$-os nyílásszögű prizmába kell helyezni a munkadarabot. Az él-lekerekítés mérési elrendezése a 2. ábrán látható.

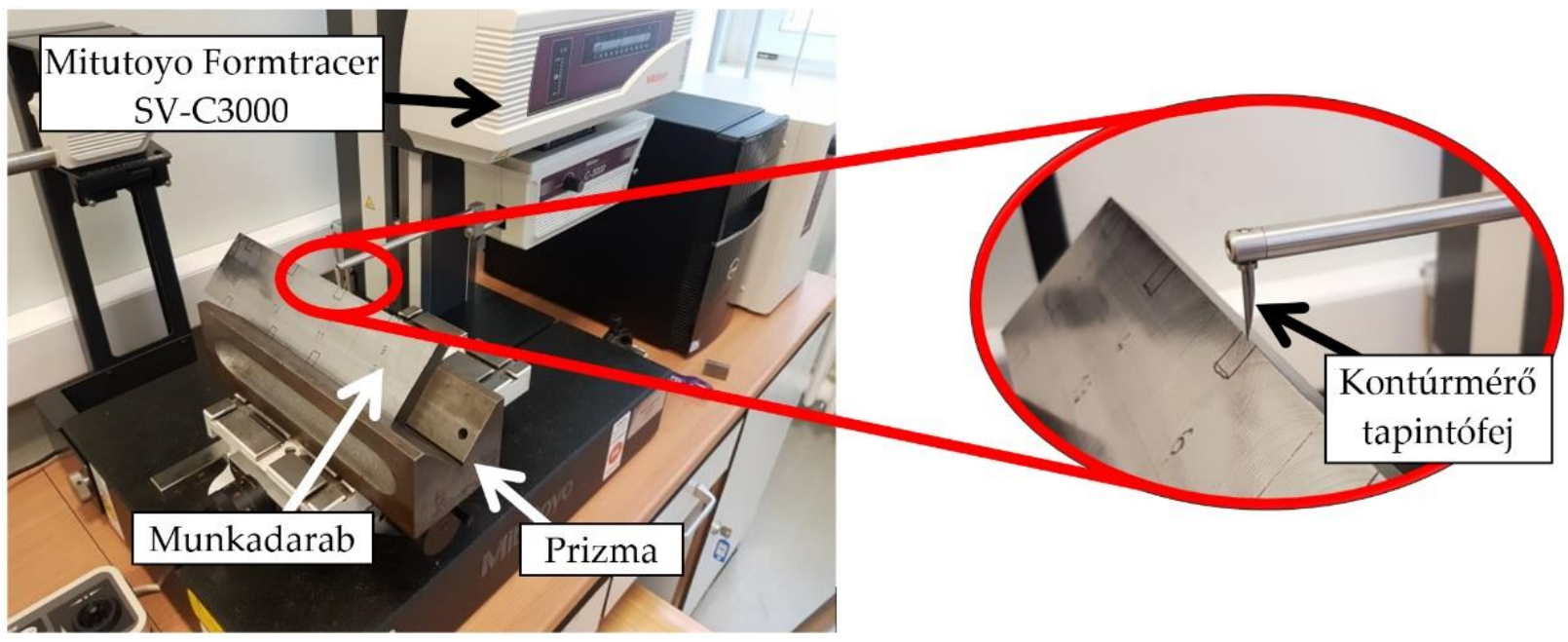

2. ábra. Az él-lekerekités mérési elrendezése

A lekerekített élek méretezései a kontúrmérést követően a kirajzolt kontúrokon a Mitutoyo konturmérő szoftverében készültek. Az 5. kísérlet mérési eredménye a 3. ábrán látható.

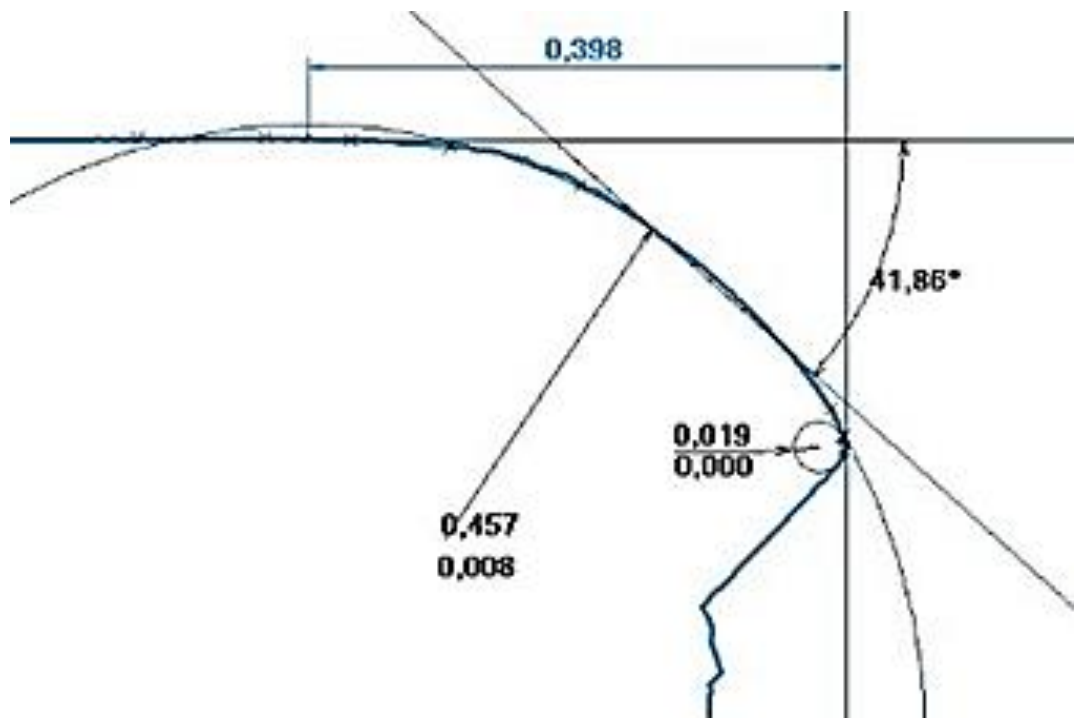

3. ábra. Az 5. kísérlet kontúrmérésének eredménye

A Mitutoyo konturmérő szoftverében lehetőség van egy görbe vagy ív kijelölésével arra egy egyenest illeszteni, mely funkció felhasználásával mértük az a szög nagyságát. 
A mérését mind a 16 kísérlettel kapott él-lekerekítésen elvégeztük, minden élt háromszor mértünk le, melyek átlagát használtuk a kísérlet kiértékeléséhez. A mérési eredmények átlagértékeit a 4. táblázat összegzi. 
4. táblázat. A lekerekitett élek méretei

\begin{tabular}{cccc}
\hline $\begin{array}{c}\text { Kísérlet } \\
\text { száma }\end{array}$ & $\begin{array}{c}\text { Lekerekített rész } \\
\text { hossza, } \\
t(\mathrm{~mm})\end{array}$ & $\begin{array}{c}\text { Legnagyobb beilleszthetö kör } \\
\text { sugara, } \\
R(\mathrm{~mm})\end{array}$ & $\begin{array}{c}\text { Lekerekített ívre illesztett } \\
\text { normális szöge, } \\
\alpha\left(^{\circ}\right)\end{array}$ \\
\hline 1 & 0,538 & 0,785 & 29,59 \\
2 & 0,359 & 1,128 & 17,6 \\
3 & 0,474 & 1,379 & 10,76 \\
4 & 0,749 & 0,576 & 36,15 \\
5 & 0,398 & 0,457 & 41,86 \\
6 & 0,659 & 0,756 & 26,87 \\
7 & 0,379 & 0,413 & 30,58 \\
8 & 0,745 & 0,552 & 44,41 \\
9 & 0,607 & 0,653 & 50,78 \\
10 & 0,423 & 0,673 & 25,31 \\
11 & 0,322 & 0,311 & 40,04 \\
12 & 0,533 & 0,501 & 40,83 \\
13 & 0,384 & 0,493 & 47,18 \\
14 & 0,447 & 0,778 & 16,97 \\
15 & 0,406 & 0,410 & 29,68 \\
16 & 0,588 & 0,640 & 33,58 \\
\hline
\end{tabular}

\section{2. Él-lekerekítések méreteinek kiértékelése}

A mért eredmények (4. táblázat) kiértékelését is a Minitab 17 statisztikai szoftver segítségével végeztük. A kiértékelés során a "Larger is better” formulát (1) használtuk, mert a létrehozott éllekerekítésnél mérhető méretek $(R, t, \alpha)$ legnagyobb értékének elérése a kutatás célja.

$$
(S / N)_{B}=-10 * \log _{10} \frac{1}{n} \sum_{i=1}^{n}\left(\frac{1}{y_{i}}\right)^{2}
$$

Mivel mindhárom vizsgált méret legnagyobb értéke más-más technológiai paraméterek alkalmazása mellett érhető el, így ezek külön kerülnek kiértékelésre. Mindegyik esetében külön meghatároztuk az alkalmazandó optimális technológiai paramétert (A-előtolási sebesség, Bhengerlési sebesség, C-szerszám túlfutás, D-megmunkálás iránya) és az arra legnagyobb hatást gyakorló faktort.

\section{a) LEKEREKÍTETT RÉSZ HOSSZA}

$A z S / N$ értékek alapján $t$-re (lekerekített rész hossza) a 4. ábrán látható hatásdiagram készült.

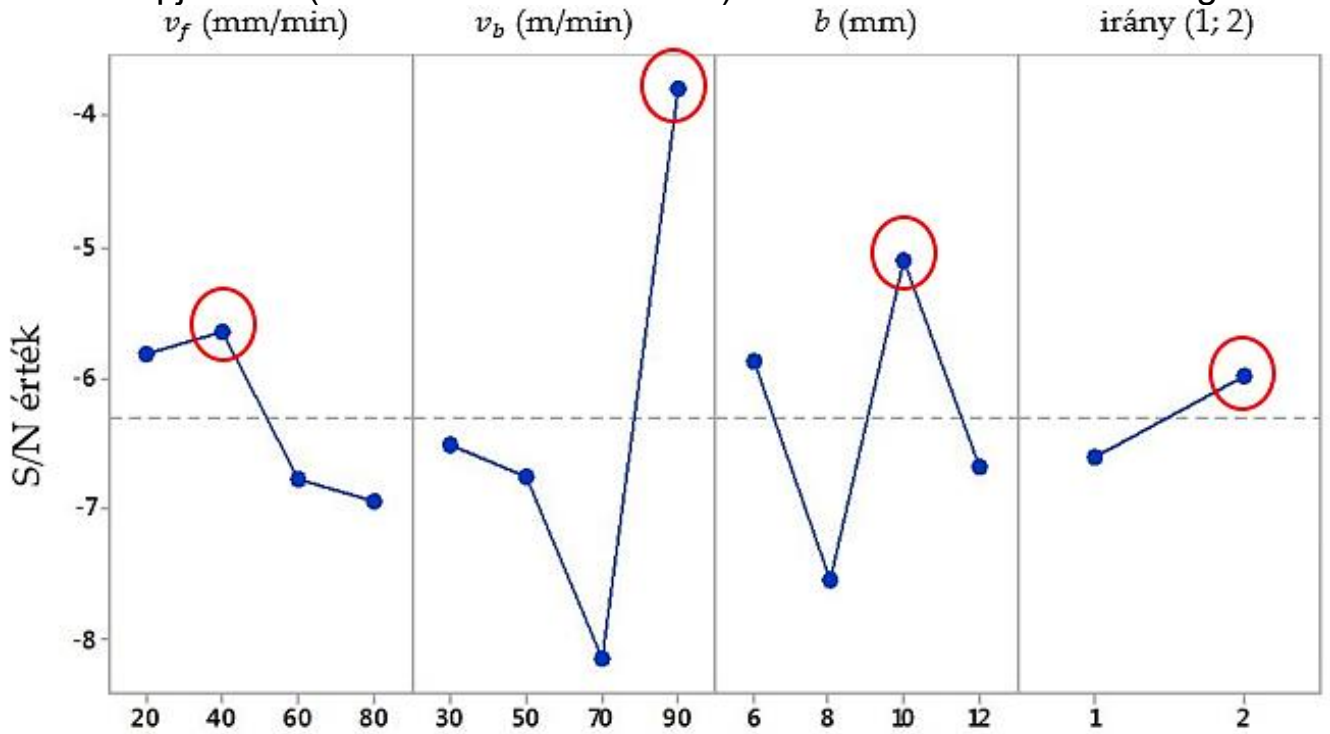

Signal-to-noise: Larger is better

4. ábra. A t-méretre számolt S/N értékek 
A 4. ábra hatásdiagramja alapján az optimális technológiai paraméterek a legnagyobb $t$ méret eléréséhez:
A-2: $v_{f}=40(\mathrm{~mm} / \mathrm{min})$
B-4: $v_{b}=90(\mathrm{~m} / \mathrm{min})$
C-3: $b=10(\mathrm{~mm})$
D-2: 2 - ellenirányú megmunkálás

Továbbá megállapítható, hogy a $t$ méret változására legnagyobb hatással a $v_{b}$ hengerlési sebesség van.

\section{b) LEGNAGYOBB BEILLESZTHETÖ KÖR SUGARA}

Az S/N értékek alapján az 5. ábrán látható „Larger is better” analízis hatásdiagram készíthető el $R$-re (legnagyobb beilleszthetö kör sugara) vonatkozóan.

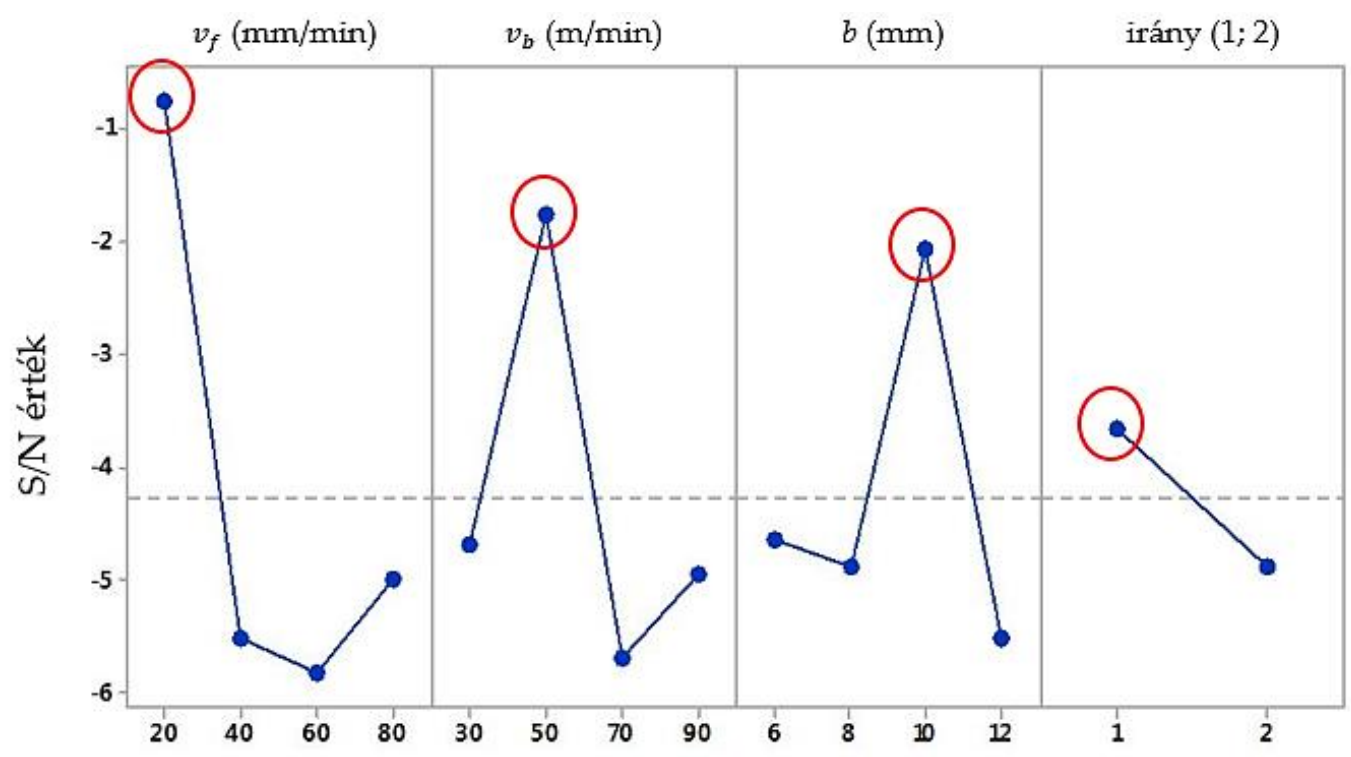

Signal-to-noise: Larger is better

5. ábra. Az R-méretre számolt S/N értékek

Az 5. ábra hatásdiagramja alapján az optimális technológiai paraméterek a legnagyobb $R$ méret eléréséhez:
A-1: $v_{f}=20(\mathrm{~mm} / \mathrm{min})$
$\mathrm{B}-2: v_{b}=50(\mathrm{~m} / \mathrm{min})$
C-3: $b=10(\mathrm{~mm})$
D-1: 1 - egyenirányú megmunkálás

Továbbá megállapítható, hogy az $R$ méret változására legnagyobb hatással a $v_{f}$ előtoló sebesség van.

c) LEKEREKÍTETT ÍVRE ILLESZTETT NORMÁLIS SZÖGE

Az S/N értékek alapján az $\alpha$-ra a 6 . ábrán látható „Larger is better” analízis hatásdiagram készíthető el (legnagyobb beilleszthető kör sugara). 


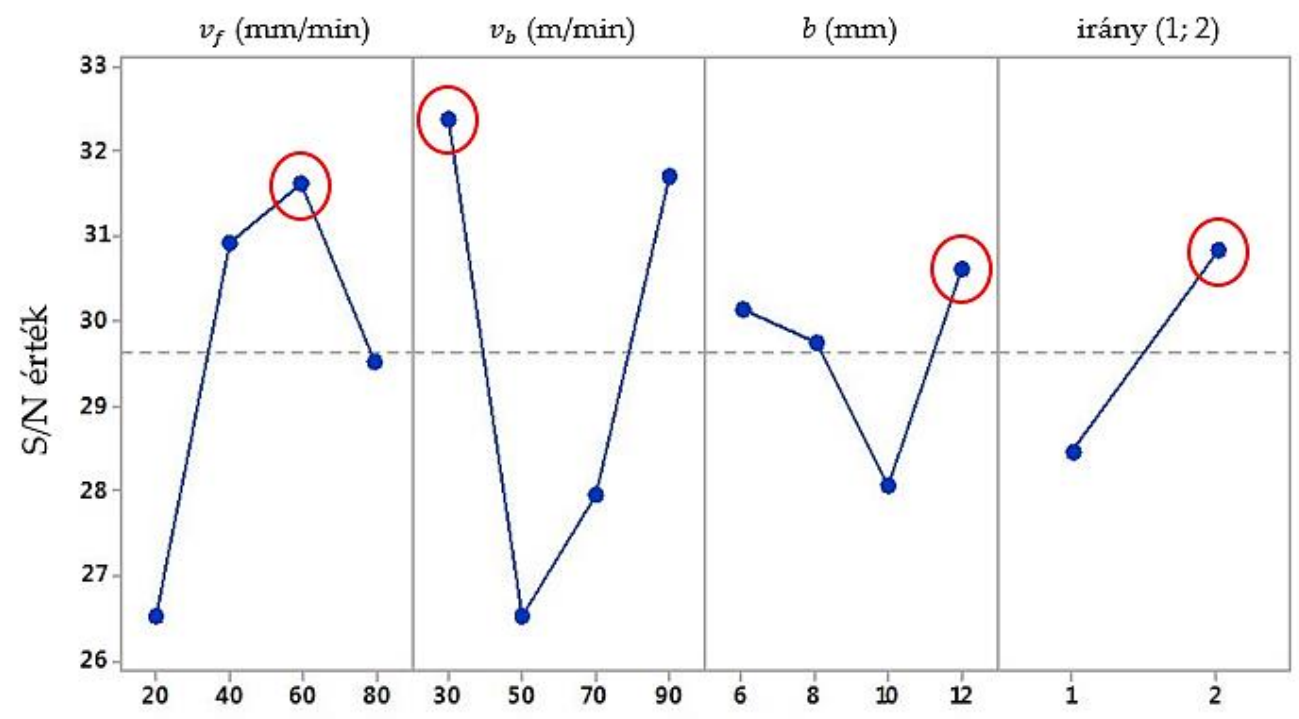

Signal-to-noise: Larger is better

6. ábra. Az a-méretre számolt $S / N$ értékek

A 6. ábra hatásdiagramja alapján az optimális technológiai paraméterek a legnagyobb $\alpha$ érték eléréséhez:
A-3: $v_{f}=60(\mathrm{~mm} / \mathrm{min})$
$\mathrm{B}-1: v_{b}=30(\mathrm{~m} / \mathrm{min})$
C-4: $b=12(\mathrm{~mm})$
D-2: 1 - ellenirányú megmunkálás

Továbbá megállapítható, hogy a $\alpha$ méret változására legnagyobb hatással a $v_{b}$ hengerlési sebesség van.

\section{4. Összegzés}

A kiértékelés eredményei alapján megállapítható, hogy mely megmunkálási paraméterek gyakorolnak legnagyobb hatást a kialakuló él-lekerekítésre. Eszerint a kísérletek során használt mágneses síkfelület hengerlő szerszámmal él-lekerekítések kialakulásában legnagyobb hatása a hengerlési sebességnek és az előtoló sebességnek van. A kiértékelés ugyanakkor azt is megmutatta, hogy a megmunkálás iránya (ellen/egyen) befolyásolja legkevésbé az él-lekerekítések létrejöttét, amit a későbbi kísérletek során ajánlatos figyelembe venni.

A kutatás során a Taguchi féle kísérlettervezési módszerrel az alábbi optimális technológiai paramétereket ajánlják a szerzők:

- ha nagy $t$ méret elérése a cél: $v_{f}=40(\mathrm{~mm} / \mathrm{min}), v_{b}=90(\mathrm{~m} / \mathrm{min}), b=10(\mathrm{~mm})$, ellenirányú megmunkálás

- ha nagy $R$ méret elérése a cél: $v_{f}=20(\mathrm{~mm} / \mathrm{min}), v_{b}=50(\mathrm{~m} / \mathrm{min}), b=10(\mathrm{~mm})$, egyenirányú megmunkálás

- ha nagy $\alpha$ méret elérése a cél: $v_{f}=60(\mathrm{~mm} / \mathrm{min}), v_{b}=30(\mathrm{~m} / \mathrm{min}), b=12(\mathrm{~mm})$, ellenirányú megmunkálás

Ahol $t(\mathrm{~mm})$ a lekerekített rész hosszát, $R(\mathrm{~mm})$ a legnagyobb beilleszthető kör sugarát, $\alpha\left(^{\circ}\right)$ a lekerekített ívre illesztett normális szögét, $v_{\uparrow}(\mathrm{mm} / \mathrm{min})$ az elötoló sebességet, $v_{b}(\mathrm{~m} / \mathrm{min})$ a hengerlési sebességet és $b(\mathrm{~mm})$ a szerszám túlfutást jelenti. 


\section{Köszönetnyilvánítás}

Köszönettel tartozunk a kutatás támogatásáért, amely az EFOP-3.6.1-16-2016-00006 „A kutatási potenciál fejlesztése és bővítése a Neumann János Egyetemen" pályázat keretében valósult meg. A projekt a Magyar Állam és az Európai Unió támogatásával, az Európai Szociális Alap társfinanszírozásával, a Széchenyi 2020 program keretében valósul meg. A kutatást részben "Kutatások az ipari digitalizáció által nyújtott potenciál minőségi kiaknázására" című ED_18-2-20180006 támogatás tette lehetővé.

Továbbá köszönettel tartozunk még dr. Mátyási Gyulának a Budapesti Műszaki és Gazdaságtudományi Egyetem, Gyártástudomány és -technológia Tanszék címzetes egyetemi tanárának a kísérletekben nyújtott segítségéért.

\section{Irodalomjegyzék}

[1] L. K. Gillespie, P. T. Blotter: The Formation and Properties of Machining Burrs. Transactions of ASME Journal of Engineers for Industry 98, (1976) pp. 66-74.

[2] M. Akuszewski: A Standard Approach to Classifying Burrs, Productionmachining (2014). https://www.productionmachining.com/articles/a-standard-approach-to-classifying-burrs (Megtekintve: 2020-05-01)

[3] J. C. Aurich, D. Dornfeld, P.J. Arrazola, V. Franke, L. Leitz, S. Min: Burrs—Analysis, control and removal, CIRP Annals - Manufacturing Technology 58, (2009) pp. 519-542 doi.org/10.1016/j.cirp.2009.09.004

[4] F. Schäfer (1975) Entgraten, Krausskopfverlag, Mainz.

[5] CNC MEDIA Kft. (2018): Új forgókefés csiszoló- és sorjátlanítógép a Timesavers-töl. https://www.cnc.hu/2018/02/uj-forgokefes-csiszologep-a-timesavers-tol/ (Megtekintve: 2020-05-01)

[6] CNC MEDIA Kft.: Csiszolás, sorjázás és éllekerekítés mesterfokon (2014) https://www.cnc.hu/2014/02/csiszolas-sorjazas-es-ellekerekites-mesterfokon/ (Megtekintve: 2020-05-01)

[7] Yoshichika Oya: Edge-rounding method and apparatus therefor, Patent number: US4078905A, Japan (1978)

[8] Kovács Zs. F.,Károly D.,Károly P. B.,Kemény D.,Kodácsy J. és Viharos Zs. J.: Mágneses erővel történő felülethengerlés hatása a felületérdességre és a korrózióra C45 acélon, Gradus vol. 3, (2016) pp. 219-226

[9] Zs. F. Kovács, Zs. J. Viharos and J. Kodácsy: Determination of the working gap and optimal machining parameters for magnetic assisted ball burnishing, Measurement vol. 118, (2018) pp. 172-180 doi.org/10.1016/j.measurement.2018.01.033

[10] Zs. F. Kovács, Zs. J. Viharos and J. Kodácsy: Surface Flatness and Roughness Evolution After Magnetic Assisted Ball, Measurement vol. 158, (2020), 107750 doi.org/10.1016/j.measurement.2020.107750

[11] J. Kodácsy, J. Líska, Zs. Kovács: Surface finishing by roller burnishing using apparatus of permanent magnet, Tehnicki Vjesnik vol. 24, (2017) pp. 49-54 